\title{
RANCANG BANGUN MESIN PENGUPAS TALAS SEMIR
}

\section{THE DESIGN OF SEMIR TARO PEELING MACHINE}

\author{
Asep Yusuf ${ }^{1}$, Wahyu K. Sugandi ${ }^{1}$, Zaida ${ }^{2}$ \\ ${ }^{1}$ Departemen Teknik Pertanian dan Biosistem,Universitas Padjadjaran \\ ${ }^{2}$ Departemen Teknologi Industri Pangan, Universitas Padjadjaran

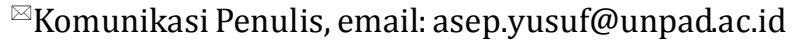 \\ DOI:http://dx.doi.org/10.23960/jtep-lv9i1.19-27
}

Naskah ini diterima pada 4 Februari 2020; revisi pada 11 Maret 2020; disetujui untuk dipublikasikan pada 13 Maret 2020

\begin{abstract}
Semir Taro is one of the leading horticultural agricultural commodities and alternative food ingredients in Sumedang Regency. However, at present the use of various processed products is still limited, taro must be made into flour first. Stripping is an important step in processing taro into flour. The manual process requires quite a long time and requires a lot of labor. Thus the role of agricultural mechanization was needed to overcome these problems, namely by designing a taro peeling machine. This research aims to design a taro peeling machine. Using engineering methods, namely the activity of designing and building a taro peeler machine. The research was conducted in April - November 2016 at the Laboratory of Agricultural Tools and Machines, Department of Agricultural Engineering and Biosystem, Faculty of Agricultural Industrial Technology, Padjadjaran University. The test results show that the machine works well with an actual capacity of $78.8 \mathrm{~kg} / \mathrm{hour}$, engine efficiency $78.74 \%$ and the peel results ware evenly distributed on all taro surfaces but still not clean because the stripping process has not been accompanied by watering using water.
\end{abstract}

Keywords: stripping, semir taro, design, machine testing

\begin{abstract}
ABSTRAK
Talas Semir merupakan salah satu komoditas pertanian hortikultura unggulan dan bahan pangan alternatif di Kabupaten Sumedang. Namun, saat ini pemanfaatannya untuk menjadi aneka produk olahan masih terbatas, talas harus dijadikan tepung terlebih dahulu. Proses pengupasan merupakan tahapan penting pada pengolahan talas menjadi tepung. Proses secara manual memerlukan waktu yang cukup lama serta membutuhkan tenaga kerja yang cukup banyak. Dengan demikian dibutuhkan peran mekanisasi pertanian untuk mengatasi masalah tersebut yaitu dengan merancang bangun mesin pengupas talas. Penelitian ini bertujuan merancang bangun mesin pengupas talas. Menggunakan metode rekayasa yaitu kegiatan merancang bangun mesin pengupas talas. Penelitian dilaksanakan pada bulan April - November 2016 bertempat di Laboratorium Alat dan Mesin Pertanian, Departemen Teknik Pertanian dan Biosistem, Fakultas Teknologi Industri Pertanian Universitas Padjadjaran. Hasil pengujian menunjukkan bahwa mesin bekerja dengan baik dengan kapasitas aktual 78,8 kg/jam, efisensi mesin $78,74 \%$ dan hasil kupasan sudah merata pada semua pemukaan talas namun masih belum bersih karena proses pengupasan belum disertai penyiraman menggunakan air.
\end{abstract}

Kata Kunci: pengupasan, talas semir, rancang bangun, pengujian mesin

\section{PENDAHULUAN}

Pangan merupakan kebutuhan pokok bagi manusia. Seiring dengan meningkatnya jumlah penduduk, maka kebutuhan pangan akan terus meningkat. Dengan demikian diperlukan peningkatan ketersediaan pangan berkelanjutan yang mampu mencukupi kebutuhan konsumsi penduduk Indonesia di masa yang akan datang. Namun kenyataannya persentase pertumbuhan produksi pangan yang berbasis karbohidrat sangat kecil, fluktuatif dan cenderung menurun. Jika laju pertumbuhan penduduk tidak diturunkan sementara laju produksi pangan sangat lamban, maka dalam beberapa tahun yang akan datang Indonesia 
berpotensi mengalami rawan pangan (Sutrisno D dan Endah D, 2011). Sesuai dengan UndangUndang No. 7 tahun 1996, Peraturan Pemerintah (PP) No. 68 tahun 2002, dan Peraturan Presiden Nomor 22 Tahun 2009, salah satu jalan keluar dari masalah kerawanan pangan adalah dengan mewujudkan diversifikasi pangan, melalui pengembangan pangan alternatif berbasis sumber daya lokal.

Masalah pangan di Indonesia tidak terlepas dari beras dan terigu, disamping bahan pangan lainnya seperti ubi kayu, jagung, dan sagu (Colas, 1994). Upaya untuk meningkatkan produksi beras bukan hal mudah, karena banyak terjadi pengalihan fungsi lahan pertanian secara massal menjadi area pemukiman dan industri. Selain itu, produksi gandum dunia terus menurun sejalan berlangsungnya cuaca ekstrem di sentra-sentra produksi gandum pada tahun 2010. Sebenarnya, Indonesia memiliki potensi umbi-umbian sebagai sumber karbohidrat sekaligus bahan baku tepung lokal. Menurut Apriani (2011), selain dengan meningkatkan jumlahnya, pemenuhan kebutuhan pangan juga dapat dilakukan dengan mengoptimalkan penggunaan sumber bahan pangan yang beraneka ragam. Salah satu sumber daya pangan lokal yang dapat dijadikan alternatif usaha diversifikasi pangan adalah talas.

Talas Sumedang (semir) merupakan salah satu komoditas pertanian hortikultura unggulan dan bahan pangan potensial di Kabupaten Sumedang. Berdasarkan data dari Dinas Pertanian Kabupaten Sumedang (2015), jumlah produksi talas semir sekitar 2.774 ton per tahun dengan luas panen seluas 243 ha. Salah satu daerah penghasil talas di Kabupaten Sumedang terdapat pada Desa Sukawening, Kampung Gorowong, Kecamatan Ganeas, Kabupaten Sumedang. Saat ini pemanfaatannya masih terbatas. Talas harus dijadikan tepung terlebih dahulu, agar lebih tahan lama dan dapat dibuat menjadi aneka produk olahan pangan. Proses pengupasan merupakan tahapan penting pada pengolahan talas menjadi tepung. Proses pengupasan secara manual memerlukan waktu yang cukup lama serta membutuhkan tenaga kerja yang cukup banyak. Hal ini menjadi kendala apabila kapasitas produksi sudah besar serta keberlanjutan (kontinyu). Dengan demikian dibutuhkan peran mekanisasi pertanian untuk mengatasi masalah tersebut yaitu dengan dirancang bangun mesin pengupas talas.

\section{BAHAN DAN METODA}

Penelitian dilaksanakan pada bulan April sampai November 2016 bertempat di Laboratorium Alat dan Mesin Pertanian, Fakultas Teknologi Industri Pertanian, Universitas Padjadjaran. Bahan yang akan digunakan adalah bahan pembuatan mesin dan bahan untuk pengujian yaitu talas sumedang (talas semir). Alat pembuatan mesin, meliputi: peralatan bengkel untuk fabrikasi mesin, dan alat Pengujian Mesin (Tabel 1).

Metode penelitian yang akan digunakan adalah metode rekayasa, yaitu kegiatan merancang bangun mesin pengupas talas. Adapun tahapan penelitian digambarkan pada Gambar 1 .

\section{Identifikasi Alat Pengupas Telah Ada}

Identifikasi bertujuan untuk mengetahui alat yang sudah ada, yang biasa digunakan oleh Petani/IKM. Serta dilihat waktu dan kualitas kupasan yang dihasilkan.

2. Penetapan Kriteria Rancangan

Berdasarkan hasil identifikasi, tahapan selanjutnya adalah penetapan kriteria rancangan. Penetapan kriteria bertujuan untuk menetukan parameter-parameter apa saja yang diharapkan dari mesin yang akan dibuat.

3. Analisis Rancangan Fungsional dan Struktural Analisis rancangan fungsional bertujuan untuk mengetahui aspek fungsional apa saja yang dari mesin pengupas talas. Sedangkan analisis struktural bertujuan untuk mengetahui bentuk, dimensi dan tata letak setiap komponen fungsional.

4. Analisis Teknik

Analisis teknik adalah proses menghitung secara matematik kekuatan bahan dan perancangan mesin yang berhubungan dengan ukuran, gaya-gaya yang bekerja dan umur dari beberapa elemen mesin yang digunakan pada mesin pengupas.

5. Pembuatan Gambar Mesin

Pembuatan gambar mesin didasarkan pada kriteria rancangan mesin yang telah 
Tabel 1. Alat Pengujian Mesin

\begin{tabular}{|c|c|c|c|}
\hline No & Alat & Spesifikasi/Ketelitian & Kegunaan \\
\hline 1 & Meteran & Ketelitian $1 \mathrm{~mm}$ & $\begin{array}{l}\text { Mengukur dimensi panjang } \\
\text { komponen }\end{array}$ \\
\hline 2 & Jangka Sorong & Ketelitian $0,05 \mathrm{~mm}$ & $\begin{array}{l}\text { Megukur ukuran talas dan } \\
\text { ketebalan plat berlubang } \\
\text { yang digunakan }\end{array}$ \\
\hline 3 & $\begin{array}{l}\text { Timbangan } \\
\text { Digital }\end{array}$ & Ketelitian 0,1 gram & $\begin{array}{l}\text { Mengukur massa talas } \\
\text { tersosoh, tidak tersosoh, dan } \\
\text { tidak tersosoh utuh }\end{array}$ \\
\hline 4 & Inverter & Thosiba & $\begin{array}{l}\text { Mengatur kecepatan putaran } \\
(\mathrm{rpm})\end{array}$ \\
\hline 5 & Tachometer & Lutron DT-223 & $\begin{array}{l}\text { Mengukurkecepatanputar } \\
\text { poros dan puli }\end{array}$ \\
\hline 6 & Vibration Meter & LutronVB-8200 & Mengukur getaran mesin \\
\hline 7 & Stopwatch & Ketelitian $1 / 10$ detik & $\begin{array}{l}\text { Mengukur waktu } \\
\text { pengupasan }\end{array}$ \\
\hline 8 & Sound Level & Lutron SL-4010 & $\begin{array}{l}\text { Mengukur tingkat kebisingan } \\
\text { mesin }\end{array}$ \\
\hline
\end{tabular}

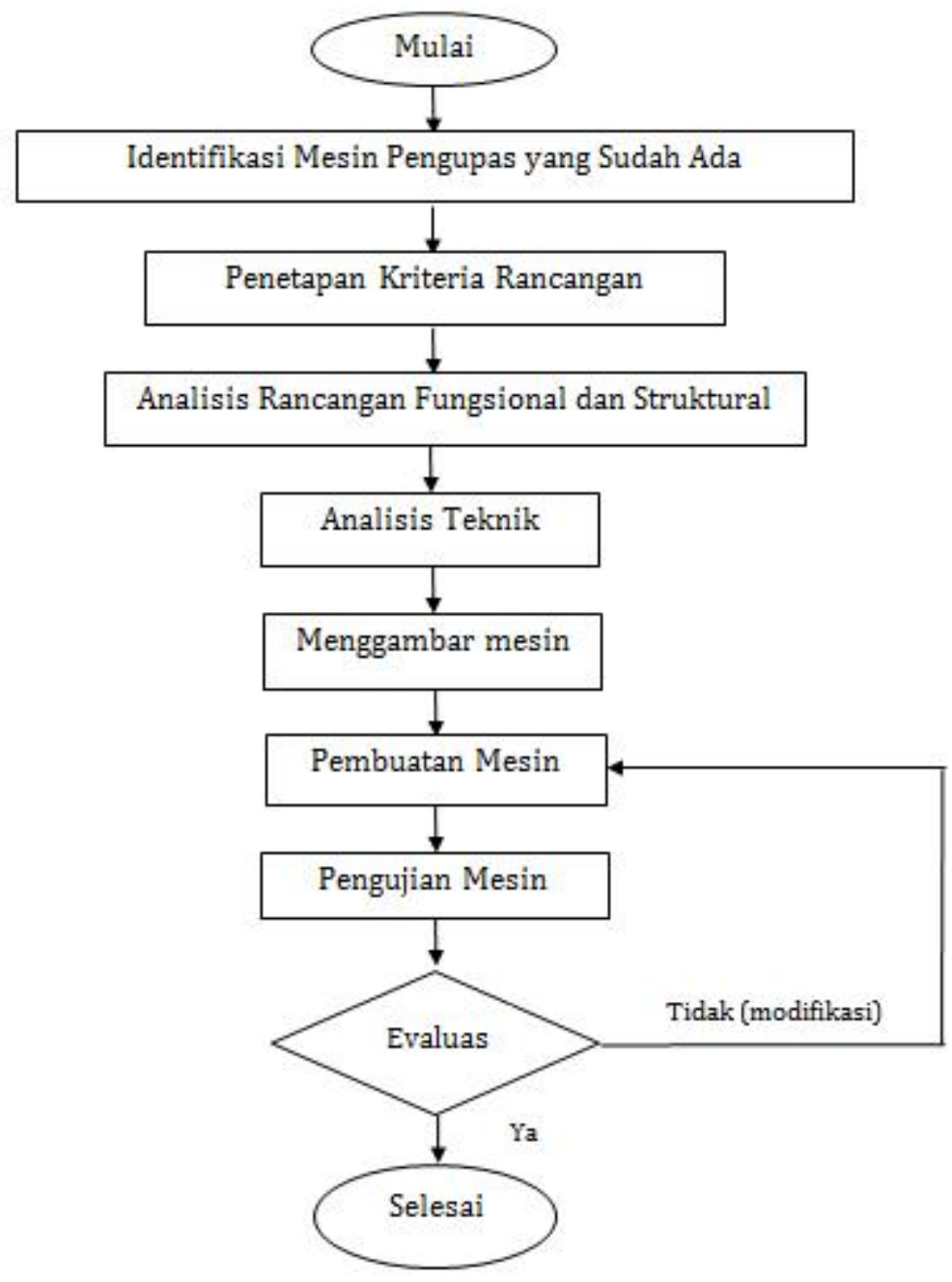

Gambar 1. Diagram Alir Penelitian 
ditetapkan. Pada kegiatan menggambar ada dua proses yang harus dikerjakan secara simultan, yaitu: analisis teknik dan menggambar. Analisis teknik adalah menghitung secara matematis beberapa komponen mesin yang digunakan dengan mengunakan data standar atau hasil pengukuran secara langsung. Proses menggambar merupakan visualisasi dari proses analisis teknik sehingga dihasilkan gambar yang mencerminkan bentuk mesin sesungguhnya yang akan dibuat.

6. Pembuatan Mesin

Mesin pengupas talas dikerjakan di Laboratorium Alat dan Mesin Pertanian, Departemen Teknik Pertanian dan Biosistem, Fakultas Teknologi Industri Pertanian Universitas Padjadjaran. Pembuatan mesin berdasarkan gambar mesin, baik bentuk maupun ukurannya.

7. Pengujian Mesin

Pengujian mesin dilakukan setelah mesin selesai dibuat. Pada pengujian dilakukan pengamatan dan pengukuran, yaitu: kinerja mesin, kapasitas mesin, getaran, kebisingan dan daya aktual mesin.

\section{HASIL DAN PEMBAHASAN}

\subsection{Perancangan Mesin Pengupas Talas}

Perancangan mesin pengupas talas didasarkan pada tahapan penelitian, dengan rincian sebagai berikut:

\subsubsection{Hasil Identifikasi Alat Pengupas yang Telah Ada}

Untuk mengetahui Alat pengupas talas yang sudah ada atau biasa digunakan petani, maka dilakukan survei dan wawancara dengan petani talas sumedang/semir di Kampung Gorowong, Desa Sukawening, Kecamatan Ganeas, Kabupaten Sumedang. Berdasarkan hasil wawancara dan pengamatan, proses pengupasan yang dilakukan petani masih dilakukan secara manual menggunakan pisau. Sehingga kapasitas pengupasan masih kecil yaitu $35 \mathrm{~kg} / \mathrm{jam}$. Data hasil pengukuran pengupasan disajikan pada Tabel 2 .

\subsubsection{Hasil Pengukuran karakteristik Fisik Talas Sumedang}

Sebelum penetapan kriteria rancangan, maka dilakukan pengukuran karakteristif fisik talas, meliputi: kebundaran, kebulatan, densitas kamba. Hasil pengukuran menunjukkan bahwa talas sumedang hampir menyerupai bentuk sebuah bola dengan jari-jari yang hampir sama. Keadaan ini ditunjukkan oleh hasil pengukuran kebulatan talas sumedang sebesar 0,88 . Dilihat dari bentuknya maka talas sumedang dapat digolongkan ke bentuk membulat atau halter menurut hasil klasifikasi menurut Minantyorini dan Hanarida (2002) dalam Koswara (2002). Sedangkan densitas kamba talas sumedang yaitu sebesar $438,94 \mathrm{~kg} / \mathrm{m}^{3}$. Tabel hasil pengukuran densitas kamba disajikan pada Tabel 3 .

\subsubsection{Penetapan Kriteria Rancangan}

Berdasarkan hasil identifikasi, tahapan selanjutnya adalah penetapan kriteria rancangan. Kriteria masin pengupas talas yaitu sebagai berikut: a) kulit talas terkupas bersih, b) kapasitas mesin $100 \mathrm{~kg} / \mathrm{jam}, \mathrm{c}$ ) cukup satu orang operator untuk mengoperasikan mesin pengupas.

\subsubsection{Hasil Analisis Rancangan Fungsional dan Struktural}

Hasil Analisis rancangan fungsional diketahui

Tabel 2. Data Hasil Pengukuran Pengupasan Secara Manual

\begin{tabular}{cccc}
\hline No & $\begin{array}{c}\text { Bobot Talas sebelum } \\
\text { dikupas (kg) }\end{array}$ & $\begin{array}{c}\text { Waktu Pengupasan, } \\
\text { menit }\end{array}$ & $\begin{array}{c}\text { Kapasitas, } \\
\mathbf{k g} / \mathbf{j a m}\end{array}$ \\
\hline 1 & 560 & 1,00 & 34 \\
2 & 525 & 0,88 & 36 \\
3 & 705 & 1,25 & 34 \\
4 & 590 & 1,05 & 34 \\
5 & 485 & 0,78 & 37 \\
\hline Rata-Rata & $\mathbf{5 7 3}$ & $\mathbf{0 , 9 9}$ & $\mathbf{3 5}$ \\
\hline
\end{tabular}


Tabel 3. Hasil Pengukuran Densitas Kamba Talas Semir

\begin{tabular}{cccc}
\hline Pengulangan & Massa talas (Kg) & Volume wadah $\left(\mathbf{m}^{3}\right)$ & Bulk density $\left(\mathbf{K g} / \mathbf{m}^{\mathbf{3}}\right)$ \\
\hline 1 & 4,95 & & 438,05 \\
2 & 4,98 & & 440,71 \\
3 & 4,96 & 0,0113 & 438.94 \\
4 & 4,96 & 438.94 \\
5 & 4,96 & 438.94 \\
6 & 4,95 & 438,05 \\
7 & 4,96 & 438.94 \\
\hline \multicolumn{3}{c}{ Rata-rata } \\
\hline
\end{tabular}

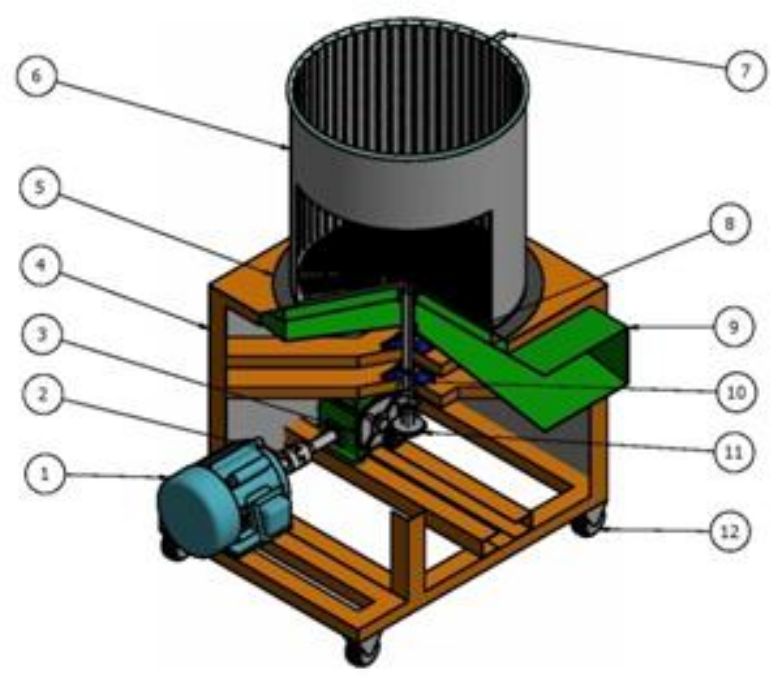

Gambar 2. Struktural Mesin Pengupas Talas

aspek fungsional meliputi: 1) motor listrik, 2) kopling tetap, 3) gearbox, 4) rangka, 5) ring penyambung, 6) silinder pengupas, 7) selang air, 8) rotor sikat, 9) saluran pengeluaran, 10) bearing, 11) roda gigi paying, dan 12) roda. Rancangan struktural mesin pengupas disajikan pada Gambar 2.

\subsubsection{Hasil Analisis Teknik}

Analisis teknik meliputi rangka, poros dan Bantalan. Hasil analisis teknik diperoleh ukuranukran dari komponen mesin meliputi: lendutan rangka 2,04 mm, lendutan ijin rangka $2,49 \mathrm{~mm}$, diameter poros $18,6 \mathrm{~mm}$, defleksi puntiran poros $0,045^{\circ}$, umur bantalan 426 juta putaran dan kapasitas dinamik bantalan 532,002 N.

\subsubsection{Gambar Mesin Pengupas}

Pembuatan gambar mesin didasarkan pada kriteria rancangan mesin yang telah ditetapkan. Pada kegiatan menggambar ada dua proses yang harus dikerjakan secara simultan, yaitu: analisis teknik dan menggambar. Analisis teknik adalah menghitung secara matematis beberapa komponen mesin yang digunakan dengan mengunakan data-data standar atau hasil pengukuran secara langsung. Proses menggambar merupakan visualisasi dari proses analisis teknik sehingga dihasilkan gambar yang mencerminkan bentuk mesin sesungguhnya yang akan dibuat Gambar Mesin Pengupas Talas disajikan pada Gambar 3.

\subsection{Mesin Pengupas Talas Hasil Rancang Bangun}

\subsubsection{Penyediaan Bahan-Bahan Pembuatan Komponen}

Komponen mesin pengupas talas terdiri dari komponen-komponen standar dan komponen yang dibuat sendiri. Komponen standar yaitu komponen yang sudah tersedia dan dijual dipasaran seperti motor listrik, gearbox, kopling dan bantalan dll. Komponen mesin tersebut 
disajikan pada Gambar 4. Sedangkan komponen yang belum ada maka harus dibuat sendiri, seperti: rangka, silinder pengupas, rotor sikat, dan lain-lain.

\subsubsection{Perakitan Komponen dan Finishing Mesin}

Setelah komponen-komponen mesin pengupas talas dibuat, maka proses selanjutnya adalah perakitan. Mesin pengupas talas dirakit di Bengkel Logam, Kayu dan Rotan, Departemen Teknik Pertanian dan Biosistem, Fakultas Teknologi Industri Pertanian Unpad. Perakitan mesin didasarkan pada gambar susunan, baik tata letak maupun ukurannya. Perakitan digunakan beberapa metode yaitu dengan cara pengelasan atau menggunakan mur dan baut. Setelah semua komponen dirakit, maka proses selanjutnya adalah proses finishing yaitu menghaluskan komponen yang tajam, menutup pori dengan cara didempul dan terakhir proses pengecatan. Pada proses pembuatan mesin pasti ada beberapa komponen yang tidak sesuai baik bentuk maupun ukurannya. Hal ini disesuaikan dengan komponen yang ada di pasaran serta kemudahan dalam proses pembuatannya. Masin pengupas talas hasil fabrikasi memiliki dimensi panjang $94 \mathrm{~cm}$, lebar $67 \mathrm{~cm}$ dan tinggi $112 \mathrm{~cm}$. Sedangkan dimensi rangka yaitu panjang $75 \mathrm{~cm}$, lebar 60 $\mathrm{cm}$ dan tinggi $56 \mathrm{~cm}$. Komponen utama mesin yaitu rangka, kopling, motor penggerak, silinder pengupas, saluran pengeluaran kulit yang terkupas, gearbox, dan roda. Mesin pengupas talas hasil rancang bangun disajikan pada Gambar 5.

Berdasarkan Gambar 5, dapat dilihat bahwa mesin pengupas hasil rancang bangun mengalami beberapa berubahan dari disain awal pada perancangan. Perubahan yang terjadi yaitu system transmisi lebih sederhana dan ringkas sehingga tidak menggunakan roda gigi kerucut karena penggunaan gearbox yang langsung ke poros sikat pengupas.

\subsubsection{Pengujian Mesin}

Pengujian mesin dilakukan setelah mesin selesai dibuat. Pada pengujian dilakukan pengamatan dan pengukuran, yaitu: getaran, tingkat kebisingan, daya aktual, kapasitas teoritis dan kapasitas aktual mesin.

\section{a. Getaran Mesin}

Getaran yang terjadi pada mesin pengupas talas terjadi karena gerakan mekanis dari elemen yang berputar dan bergesekan yaitu motor penggerak, rotor sikat dan gesekan antara buah talas dengan silinder pengupas. Pengukuran getaran ini menggunakan alat vibration meter, dengan titik pengukuran pada bagian rangka dan silinder pengupas.

Berdasarkan hasil pengukuran, getaran mesin pengupas talas saat beban kosong yaitu pada

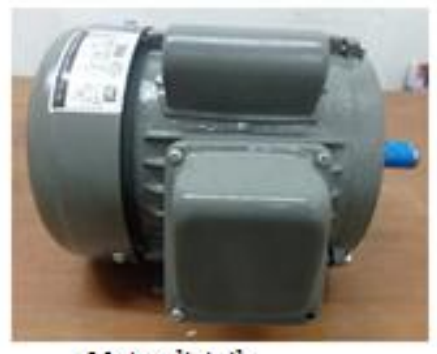

Motor listrik

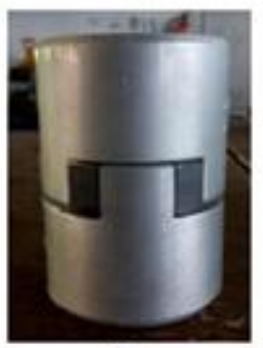

Kopling

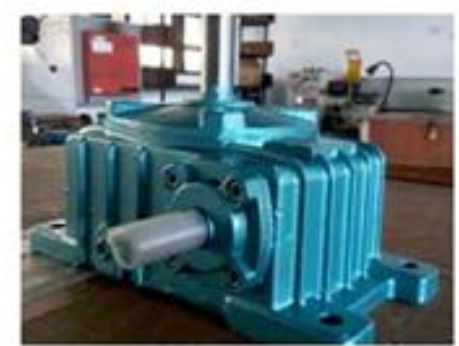

Gearbox

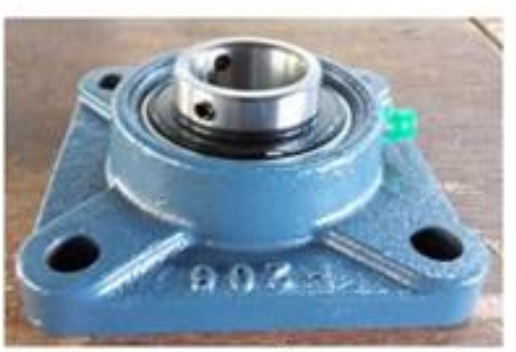

Bantalan

Gambar 4. Komponen Mesin Standar 


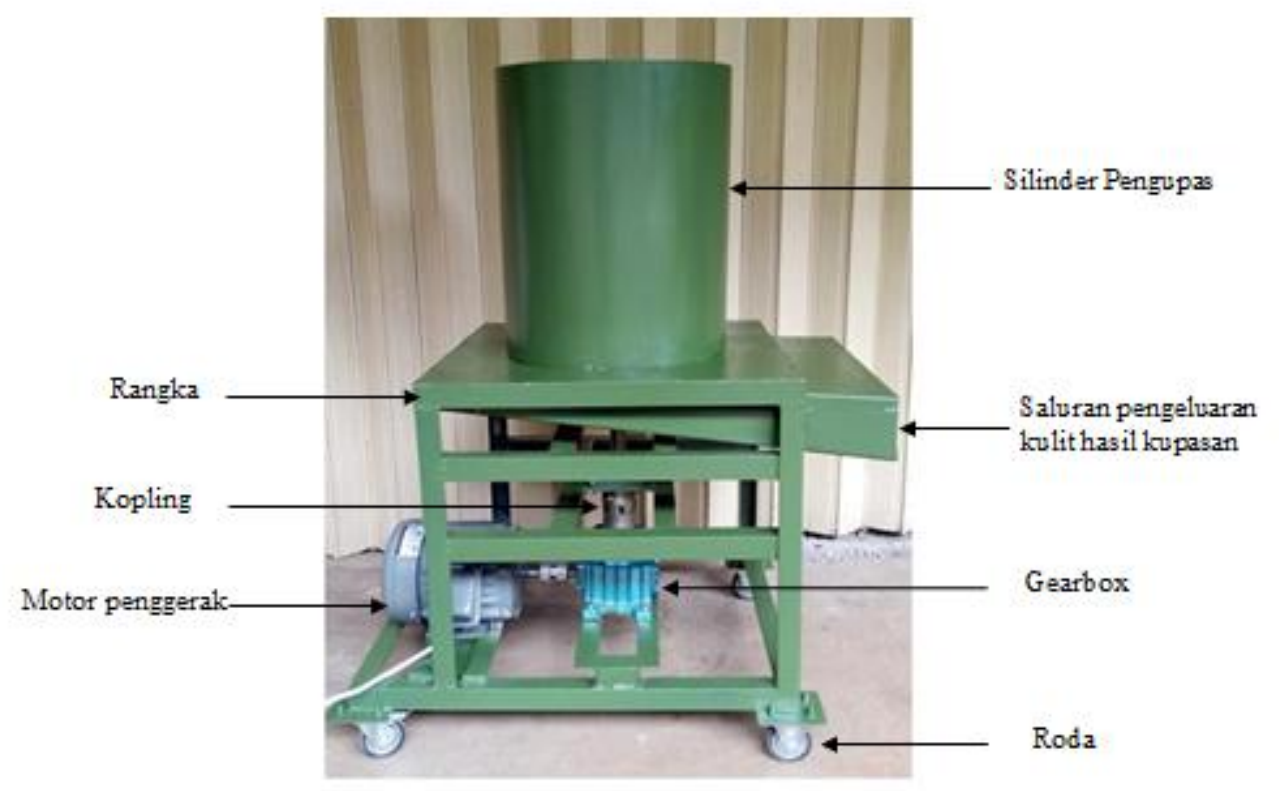

Gambar ๖. Mesin Pengupas 'lalas Hasil Kancang Bangun

rangka sebesar $11,0 \mathrm{~mm} / \mathrm{s}$ dan silinder pengupas sebesar 4,7 mm/s. Sedangkan, getaran mesin pada saat pengupasan yaitu pada rangka sebesar $5,2 \mathrm{~mm} / \mathrm{s}$ dan pada silinder pengupas sebesar 5,4 $\mathrm{mm} / \mathrm{s}$.

Berdasarkan Keputusan Menteri Tenaga Kerja Nomor:Kep-51/Men/1999 tentang nilai ambang batas faktor fisik di tempat kerja, getaran yang diizinkan untuk mesin yang menggunakan motor listrik sebesar $4 \mathrm{~mm} / \mathrm{s}$. Melihat hasil pengukuran yang dilakukan maka getaran yang terdapat pada mesin pengupas talas ini berada di atas nilai ambang batas yang diizinkan terutama pada bagian rangka. Hal ini disebabkan karena sumber getaran yang berasal dari motor listrik dan gesekan yang terjadi pada proses pengupasan yang besar. Selain itu, peredam yang digunakan pun hanya terletak pada roda beralaskan karet saja. Namun, mengingat pengoperasian mesin ini tidak terjadi kontak yang sering antara operator dengan mesin maka kemungkinan besarnya getaran pada mesin ini tidak memberikan dampak secara signifikan serhadap kesehatan operator.

\section{b. Tingkat Kebisingan}

Pengukuran tingkat kebisingan dilakukan dengan menggunakan alat soundlevel meter. Pengukuran tingkat kebisingan pada mesin pengupas talas ini dilakukan sebanyak lima kali ulangan pada jarak $2 \mathrm{~m}$ dari sumber bunyi.
Berdasarkan hasil pengukuran kebisingan mesin pengupas talas dilakukan tanpa beban dan beban isi dengan nilai masing-masing yaitu $92,2 \mathrm{~dB}$ dan $94,5 \mathrm{~dB}$. Nilai kebisingan ini berada diatas nilai ambang batas kebisingan yang diizinkan yaitu $85 \mathrm{dBA}$ untuk waktu kontak dengan mesin selama 8 jam perhari sehingga dilihat dari aspek kebisingannya, mesin pengupas talas ini aman dan layak untuk digunakan untuk waktu 4 jam/ hari.

\section{c. Daya Aktual Mesin}

Kebutuhan daya dihitung untuk mengetahui energi yang diperlukan oleh mesin untuk melakukan pengupasan talas. Pengukuran kebutuhan daya dilakukan pada saat tanpa beban dan pada saat beban isi (pengupasan). Pengukuran kebutuhan daya pada mesin ini menggunakan clamp power pada motor listrik. Berdasarkan Hasil pengukuran kebutuhan daya mesin pengupas (Tabel 4) dapat dilihat bahwa kebutuhan daya mengalami peningkatan ketika ada beban. Hal ini disebabkan ada daya tambahan untuk proses pengupasan.

\section{d. Kapasitas Teoritis}

Kapasitas teoritis mesin pengupas talas merupakan kapasitas mesin untuk melakukan pengupasan berdasarkan variabel dan dimensi elemen mesin pengupas. Jari-jari silinder pengupas $20 \mathrm{~cm}$, tinggi ruang pengupasahan 30 $\mathrm{cm}$, densitas kamba talas $438,94 \mathrm{~kg} / \mathrm{m}^{3}$, dan 
Tabel 4. Hasil Pengukuran Daya Aktual Mesin

\begin{tabular}{ccc}
\hline No. & Tanpa Beban (Watt) & Beban Isi (Watt) \\
\hline 1. & 425 & 467 \\
2. & 426 & 471 \\
3. & 423 & 479 \\
4. & 424 & 474 \\
5. & 426 & 466 \\
6. & 427 & 465 \\
7. & 424 & 477 \\
8. & 425 & 471 \\
9. & 424 & 461 \\
10. & 421 & 472 \\
\hline Rata-rata & $\mathbf{4 2 4 , 5}$ & $\mathbf{4 7 0 , 3}$ \\
\hline
\end{tabular}

waktu pengupasan selama 10 menit. Berdasarkan variabel tersebut didapatkan kapasitas teoritis mesin pengupas talas sebesar $100,08 \mathrm{~kg} / \mathrm{jam}$.

\section{e. Kapasitas Aktual Mesin}

Kapasitas aktual mesin pengupas talas dihitung berdasarkan jumlah talas yang dikupas dalam selang waktu yang digunakan untuk proses pengupasan. Hasil perhitungan kapasitas aktual mesin pengupas talas yaitu $78,80 \mathrm{~kg} / \mathrm{jam}$.

\section{f. Efisiensi Mesin}

Efisiensi mesin pengupas talas merupakan perbandingan antara kapasitas aktual mesin dengan kapasitas teoritisnya. Berdasarkan hasil perhitungan efisiensi mesin pengupas talas ini yaitu $78,74 \%$. Nilai ini menunjukkan mesin pengupas tersebut telah memiliki efisiensi yang cukup baik dan artinya kemampuan mesin hasil rancang bangun telah sesuai dengan analisis perancangan dan perhitungan secara teoritis.

\section{KESIMPULAN DAN SARAN}

\subsection{Kesimpulan}

Mesin pengupas talas telah berhasil dirancang bangun dengan komponen utama terdiri dari: rangka, kopling, motor penggerak, silinder pengupas, saluran pengeluaran kulit yang terkupas, gearbox, dan roda. Dimensi mesin pengupas talas yaitu panjang $94 \mathrm{~cm}$, lebar $67 \mathrm{~cm}$ dan tinggi $112 \mathrm{~cm}$. Sedangkan dimensi rangka yaitu panjang $75 \mathrm{~cm}$, lebar $60 \mathrm{~cm}$ dan tinggi 56 $\mathrm{cm}$. Hasil pengujian menunjukkan bahwa mesin bekerja dengan baik dengan kapasitas aktual 78,8 $\mathrm{kg} / \mathrm{jam}$, efisensi mesin 78,74\% dan hasil kupasan sudah merata pada semua pemukaan talas namun masih belum bersih karena proses pengupasan belum disertai penyiraman menggunakan air.

\subsection{Saran}

Perlu dilakukan pengujian dimana pada saat mengupas disiram menggunakan air sehingga talas yang dikupas terlihat bersih dan kulit hasil kupasan cepat keluar melalui saluran pengeluaran. Getaran mesin cukup tinggi terutama pada bagian rangka, sehingga perlu dipasang peredam getaran.

\section{DAFTAR PUSTAKA}

Apriani, N.R., Setyadjit, M. Arpah, 2011. Karakteristik Empat Jenis Umbi Talas Varian Mentega, Hijau, Semir, dan Beneng Serta Tepung Yang Dihasilkan Dari Keempat Varian Umbi Talas. Jurnal IImu Pangan (1) 1

Colas, A. 1994. Defining Flour Quality According to Use. In Godon B., and Williem C. (Eds). Primary Cereal Processing. VCR, 452-517.

Dinas Pertanian. 2015. Realisasi Luas Panen, Produksi, dan Pengolahan Talas Semir. Dinas Pertanian, Peternakan dan Perikanan. Kabupaten Sumedang. 
Koswara S. 2013. Modul Teknologi Pengolahan Umbi-Umbian Bagian 1: Pengolahan Umbi Talas. Southeast Asian Food And Agricultural Science and Technology (SEAFAST) Center. IPB. Bogor
Sutrisno D., Endah D. 2011 Prospek Agrobisnis Talas Sebagai Bahan Pangan Alternatif, Fakultas Pertanian UNPAD. 